\section{Reduction in Transpiration and Return Bloom in Apple by Two Sterol-inhibiting Fungicides}

\author{
Alan R. Biggs ${ }^{1}$ \\ West Virginia University, University Experiment Farm, P. O. Box 609, \\ Kearneysville, WV 25430
}

Additional index words. Malus domestica, bitertanol, flusilazole

\begin{abstract}
The proportion of spurs blooming on 'McIntosh' apples (Malus domestica Borkh.) was reduced significantly in 1986 and 1988, but not in 1987, following seasonal programs of six bitertanol or flusilazole treatments applied at two and three rates, respectively. The fungicides were not associated with any visible phytotoxic effect nor was shoot length reduced by any fungicide treatment. In two of three experiments conducted in May and June 1986, transpiration was reduced by the low rate of flusilazole and the high rate of bitertanol relative to both the captan and nonsprayed trees. In all three experiments, flusilazole at $1.4 \mathrm{~g}$ a.i./100 liter was associated with transiently reduced transpiration rates, lasting a minimum of $\mathbf{4 8}$ hours, relative to the nonsprayed control. Fungicides affected the diffusive resistance of apple leaves in all three experiments; however, there were no consistent treatment effects on diffusive resistance among the three experiments.
\end{abstract}

Sterol-inhibiting fungicides currently are among the fungicides available for controlling several important diseases of apples in the United States and elsewhere. This group of fungicides is noted mainly for its improved post-infection activity when compared to protective materials such as captan or mancozeb (Kelley and Jones, 1981; Szkolnik, 1981). Most agricultural chemicals have effects on nontarget microorganisms or on the plant systems in which they are used (Vyas, 1988). Because sterol-inhibiting fungicides are a relatively new class of compounds, there is very little literature on their nontarget effects. Given that these materials have the potential for widespread use on tree fruits, particularly since the withdrawal of the ethylene bisdithiocarbamate (EBDC) fungicides, the objective of this study was to determine, in the orchard, what impact, if any, their regular use would have on return bloom, shoot length, and diffusive resistance and transpiration, i.e., two production-related physiological characteristics.

The experiments were conducted in an orchard of 'McIntosh' trees on M.26 rootstock established in 1976 and spaced at $2.4 \times 4.9$ $\mathrm{m}$. Three-tree plots were arranged in four blocks as a randomized complete-block design. Guard rows were positioned between treated trees and between blocks (rows) to minimize the effect of spray drift. Fungicides were applied to runoff with a handgun attached to a John Bean plot sprayer (FMC, Jonesboro, Ark.) operating at $2760 \mathrm{kPa}$. The

\footnotetext{
Received for publication 12 Jan. 1990. This research was conducted while the author was Research Scientist and Head, Plant Pathology Section, Agriculture Canada, Research Station, Vineland Station, Ont., LOR 2E0 Canada. Appreciation is extended to Ann Curwin and Len Mancini for their technical assistance and to David A. Rosenberger for reading the original manuscript.

${ }^{1}$ Associate Professor of Plant Pathology.
}

located on opposite sides of the trunk. The total number of spurs, spurs with blossoms, and percentage of total spurs with blossoms were determined on 15 May 1986, 27 May 1987, and 26 May 1988. The data collected on these dates reflect the effects of fungicides applied on 7 and 21 May, 3 and 19 June, and 11 and 30 July 1985; 13 and 27 May, 11 and 25 June, and 9 and 23 July 1986; and 6 and 21 May, 3 and 16 June, and 8 July 1987.

The lengths of elongating terminal shoots were determined toward the end of the fungicide program in each year. Data were collected from 10 shoots per tree sampled from all around the perimeter of the tree. Shoot lengths were measured on 27 June 1985, 25 June 1986, and 10 July 1987 and reflect the effects of fungicides applied on 7 and 21 May, and 3 and 19 June 1985; 13 and 27 May, and 19 June 1986; and 6 and 21 May, and 3 and 16 June 1987.

Transpiration and diffusive resistance were measured with a steady state porometer fitted with the $2.0-\mathrm{cm}^{2}$ broadleaf aperture cap (model LI-1600, LI-COR, Inc., Lincoln, Neb.). Data were collected from the fourth expanded leaf from the shoot apex of each of three terminals per tree located on the side of the tree facing east. The data were collected between $\approx 0800$ to $1230 \mathrm{HR}$. The orchard was sampled in a serpentine manner so that variations in transpiration and diffusive resistance due to changes in solar radiation, leaf temperature, relative humidity, and wind during the sampling period would be part of the block effect in the statistical analyses. Leaf temperature and quantum radiation were recorded at the beginning of each block. Quantum radiation ranged from 880 to 1950,156 to 2430 , and 580 to 919 $\mu \mathrm{mol} \cdot \mathrm{s}^{-1} \cdot \mathrm{m}^{-2}$ on 28 May, 13 June, and 27 June 1986, respectively. Leaf temperatures ranged from 21.2 to $30.7,17.9$ to 26.2 , and 22.4 to $24.2 \mathrm{C}$ on each of the three dates listed above, respectively. Given the profound influence of environmental conditions on transpiration and diffusive resistance, no attempt was made to compare the pre- and post-application absolute values of these measurements. The null hypothesis that there

$\mathrm{cm}$ sections of branch per tree located $\approx 1 \mathrm{~m}$ from ground level. The two branches were

Table 1. Length of 'McIntosh' apple terminal shoots treated with sterol-inhibiting fungicides bitertanol and flusilazole in 1985, 1986, and 1987.

\begin{tabular}{|c|c|c|c|}
\hline \multirow{3}{*}{$\begin{array}{c}\text { Fungicide }^{2} \\
\text { (g a.i./100 liter) }\end{array}$} & \multicolumn{3}{|c|}{ Length of shoot $(\mathrm{cm})$} \\
\hline & \multicolumn{3}{|c|}{ Evaluation date } \\
\hline & 27 June 1985 & 25 June 1986 & 10 July 1987 \\
\hline $\begin{array}{l}\text { Bitertanol (8.4) } \\
(16.8)\end{array}$ & $\begin{array}{l}24.4 \mathrm{a} \\
21.8 \mathrm{bc}\end{array}$ & $\begin{array}{l}37.8 \mathrm{a} \\
38.5 \mathrm{a}\end{array}$ & $\begin{array}{l}37.5 \mathrm{ab} \\
37.1 \mathrm{ab}\end{array}$ \\
\hline Captan (70) & $22.5 \mathrm{abc}$ & $35.5 \mathrm{~b}$ & $36.6 \mathrm{ab}$ \\
\hline Flusilazole (1.4) & $21.4 \mathrm{c}$ & $37.9 \mathrm{a}$ & $37.5 \mathrm{ab}$ \\
\hline$(2.8)$ & $23.4 \mathrm{ab}$ & $38.0 \mathrm{a}$ & $39.3 \mathrm{a}$ \\
\hline$(5.6)$ & $23.5 \mathrm{ab}$ & $37.7 \mathrm{a}$ & $38.2 \mathrm{a}$ \\
\hline No fungicide & $23.8 \mathrm{ab}$ & $34.6 \mathrm{~b}$ & $35.2 \mathrm{~b}$ \\
\hline$P<0$ & 0.002 & 0.0001 & 0.05 \\
\hline
\end{tabular}

${ }^{2}$ Fungicide treatments applied on 7 and 21 May, and 3 and 19 June 1985; 13 and 27 May, and 9 June 1986; 6 and 21 May, and 3 and 16 June 1987. In 1985 the lower rate of bitcrtanol was tank-mixed with $70 \mathrm{~g}$ captan/100 liter.

yData are means from 120 terminal shoots from a randomized complete-block design with four blocks, three replicate trees per treatment, and 10 shoots per tree.

${ }^{x}$ Mean separation in columns by Duncan's multiple range test, $P<0.05$. 
Table 2. Numbers of spurs, numbers of spurs with blossoms, and percentage of spurs with blossoms from 'McIntosh' apple trees treated with bitertanol, captan, and flusilazole in 3 years. ${ }^{2, y}$

\begin{tabular}{|c|c|c|c|c|c|c|c|c|c|}
\hline \multirow[b]{2}{*}{$\begin{array}{c}\text { Fungicide }^{\mathbf{x}} \\
\text { (a.i./100 liter) }\end{array}$} & \multicolumn{3}{|c|}{15 May 1986} & \multicolumn{3}{|c|}{27 May 1987} & \multicolumn{3}{|c|}{26 May 1988} \\
\hline & $\begin{array}{l}\text { Spurs } \\
\text { (no.) }\end{array}$ & $\begin{array}{l}\text { Spurs with } \\
\text { blossoms } \\
\text { (no.) }\end{array}$ & $\begin{array}{c}\text { Spurs with } \\
\text { blossoms } \\
(\%)\end{array}$ & $\begin{array}{l}\text { Spurs } \\
\text { (no.) }\end{array}$ & $\begin{array}{l}\text { Spurs with } \\
\text { blossoms } \\
\text { (no.) }\end{array}$ & $\begin{array}{l}\text { Spurs with } \\
\text { blossoms } \\
(\%)\end{array}$ & $\begin{array}{l}\text { Spurs } \\
\text { (no.) }\end{array}$ & $\begin{array}{c}\text { Spurs with } \\
\text { blossoms } \\
\text { (no.) }\end{array}$ & $\begin{array}{c}\text { Spurs with } \\
\text { blossoms } \\
(\%)\end{array}$ \\
\hline Bitertanol (8.4) & 14.4 & $9.3 \mathrm{c}$ & $64.8 \mathrm{~b}$ & 20.2 & 3.0 & 14.8 & 17.7 & 5.8.ab & $32.8 \mathrm{ab}$ \\
\hline$(16.8)$ & 14.0 & $10.2 \mathrm{bc}$ & $72.7 \mathrm{~b}$ & 19.9 & 1.8 & 9.0 & 17.5 & $6.6 \mathrm{ab}$ & $37.7 \mathrm{ab}$ \\
\hline Captan (70) & 15.1 & $14.0 \mathrm{a}$ & $93.0 \mathrm{a}$ & 19.1 & 1.5 & 7.8 & 17.7 & $10.7 \mathrm{a}$ & $60.4 \mathrm{a}$ \\
\hline Flusilazole (1.4) & 16.3 & $11.8 \mathrm{~b}$ & $72.2 \mathrm{~b}$ & 21.2 & 3. & 15.6 & 17.9 & $3.8 \mathrm{~b}$ & $21.2 \mathrm{~b}$ \\
\hline$(2.8)$ & 14.2 & $9.0 \mathrm{c}$ & $63.6 \mathrm{~b}$ & 20.8 & 4.6 & 22.1 & 17.5 & $3.2 \mathrm{~b}$ & $18.3 \mathrm{~b}$ \\
\hline$(5.6)$ & 15.0 & $10.6 b c$ & $70.8 \mathrm{~b}$ & 21.0 & 4.5 & 21.4 & 16.9 & $5.8 \mathrm{ab}$ & $34.3 \mathrm{ab}$ \\
\hline No fungicide & 14.0 & $10.1 \mathrm{bc}$ & $72.4 \mathrm{~b}$ & 19.3 & 1.4 & 7.2 & 17.2 & $7.3 \mathrm{ab}$ & $42.4 \mathrm{ab}$ \\
\hline$P<$ & 0.16 & 0.01 & 0.01 & 0.36 & 0.26 & 0.14 & 0.96 & 0.05 & 0.05 \\
\hline
\end{tabular}

${ }^{2}$ Data are means from twenty-four $60-\mathrm{cm}$ branch lengths from a randomized complete-block design with four blocks, three replicate trees per treatment, and two branches per tree.

yMean separation in columns by Duncan's multiple range test, $P<0.05$

×Sprays applied on 7 and 21 May, 3 and 19 June, and 11 and 30 July 1985; 13 and 27 May, 11 and 25 June, and 9 and 23 July

1986; 6 and 21 May, 3 and 16 June, and 8 July 1987. In 1985 the lowest rate of bitertanol was tank-mixed with $70 \mathrm{~g}$ captan/liter.

Table 3. Diffusive resistance of 'McIntosh' apple leaves before and after application of the sterolinhibiting fungicides bitertanol and flusilazole., , y $^{2}$

\begin{tabular}{|c|c|c|c|c|c|c|}
\hline \multirow{3}{*}{$\begin{array}{c}\text { Treatment }^{x} \\
\text { (g a.i. } / 100 \text { liter) }\end{array}$} & \multicolumn{6}{|c|}{ Diffusive resistance $\left(\mathrm{s}^{\prime} \mathrm{cm}^{-1}\right)$} \\
\hline & \multicolumn{2}{|c|}{ Application I } & \multicolumn{2}{|c|}{ Application II } & \multicolumn{2}{|c|}{ Application III } \\
\hline & Pre- & Post- & Pre- & Post- & Pre- & Post- \\
\hline$\overline{\text { Bitertanol (8.4) }}$ & 1.06 & $1.96 \mathrm{a}$ & 1.58 & $1.59 \mathrm{~cd}$ & 3.68 & $2.78 \mathrm{c}$ \\
\hline$(16.8)$ & 1.02 & $1.78 \mathrm{a}$ & 1.68 & $1.99 \mathrm{a}$ & 3.36 & $3.04 \mathrm{bc}$ \\
\hline Captan (70) & 0.88 & $1.43 \mathrm{~b}$ & 1.56 & $1.40 \mathrm{~d}$ & 3.34 & $3.46 \mathrm{a}$ \\
\hline Flusilazole (1.4) & 0.99 & $1.83 \mathrm{a}$ & 1.62 & $1.94 \mathrm{a}$ & 3.89 & $3.57 \mathrm{a}$ \\
\hline$(2.8)$ & 0.99 & $1.78 \mathrm{a}$ & 1.65 & $1.83 \mathrm{ab}$ & 3.78 & $3.19 \mathrm{ab}$ \\
\hline$(5.6)$ & 0.86 & $1.77 \mathrm{a}$ & 1.61 & $1.83 \mathrm{ab}$ & 3.60 & $3.47 \mathrm{a}$ \\
\hline No fungicide & 0.90 & $1.78 \mathrm{a}$ & 1.65 & $1.68 \mathrm{bc}$ & 3.65 & $3.17 \mathrm{abc}$ \\
\hline$P<$ & 0.14 & 0.0001 & 0.85 & 0.0001 & 0.21 & 0.0001 \\
\hline
\end{tabular}

${ }^{2}$ Data are the means of 36 measurements from a randomized complete-block design with four blocks, three replicate trees per treatment, and three leaves per tree. Measurements taken from the fourth expanded leaf from the terminal shoot apex.

YMean separation in columns by Duncan's multiple range test, $P<0.05$.

×Sprays were applied on 27 May, 10 and 25 June and pre- and post-application measurements were taken on 26 and 28 May, 9 and 13 June, and 24 and 27 June 1986, respectively. Applications I, II, and III represent the second, third, and fourth seasonal fungicide application to the orchard (first spray was applied on 12 May).

would be an absence of a significant treatment effect at both pre- and post-application measurements was tested. The desiccant in the sensor and on the instrument panel was renewed before each day's measurements and salt cup and micropipette calibrations were performed on the instrument before each experiment.

All data from the measurements described above were subjected to analysis of variance based on a randomized complete-block design. If a particular analysis was significant at $P<0.05$, means were separated with Duncan's multiple range test $(P<0.05)$ (Steel and Torrie, 1980).

In 1985 , shoot length was reduced by 1.4 $\mathrm{g}$ a.i./100 liter flusilazole relative to the nonsprayed trees but was not significantly different from trees treated with captan or the high rate of bitertanol (Table 1). In 1986, all sterol-inhibiting fungicide treatments induced increased shoot length relative to captan and nonsprayed trees. In 1987, only the moderate and high rates of flusilazole increased shoot length relative to the nonsprayed control. Differences in shoot length relative to the nonsprayed control in 1986 and 1987 were probably due to the severe apple scab epiphytotic experienced in 1986 (Biggs and Warner, 1987). In general, there was no direct effect of sterol-inhibiting fungicide treatments on the length of 'McIntosh' terminal shoots. Locke and Andrews (1986) reported shorter internode length of 'Cox's Orange Pippin' apple shoots treated with triadimefon and fenarimol relative to those treated with binapacryl. In their experiments, trees had been sprayed with fungicides up to 18 times during the season over the past five seasons. That many sprays are not likely to be used in U.S. orchards because of the potential for development of pathogen resistance. Shoot length reductions caused by triazole fungicides also have been reported for soybeans, peas, radishes, and tomatoes (Buchenauer et al., 1984; Fletcher and Nath, 1984). In these experiments, reduced shoot elongation was accompanied by morphological changes in the foliage. Altered morphology of apple foliage has been observed following treatments with sterolinhibiting fungicides (Church et al., 1984; Kelley and Jones, 1981; Szkolnik, 1981); however, there were no visible phytotoxic or growth-regulator effects that could be attributed to either of the sterol-inhibiting fungi- tides used in these experiments.

There was no effect on fungicide treatments on the numbers of spurs on apple branches during the 3 years they were counted. However, blossom numbers and percentage of spurs with blossoms were reduced by some sterol-inhibiting fungicide treatments relative to the captan treatment in 2 of the 3 years (Table 2). In 1986, all sterol-inhibiting fungicide treatments were associated with reduced return bloom, relative to captan, with blossom reductions in the range of $20 \%$ to $30 \%$. In 1988 , only the low and moderate rates of flusilazole were associated with reduced return bloom. The severe apple scab epiphytotic of 1986 probably contributed to the greatly reduced numbers of blossoms in 1987, although disease incidence in the moderate and high flusilazole treatments was not severe enough to be the sole cause for the observed reductions, i.e., only $2.9 \%$ and $0.1 \%$ of terminals with lesions (Biggs and Warner, 1987). It seems clear from the data in Table 2 that sterol-inhibiting fungicides can influence return bloom on apple. Our data confirm those of Latham et al. (1985) who observed reduced return bloom of 'Redspur Delicious' apples after season-long programs of bitertanol and etaconazole.

No explanation for the effect of sterol-inhibiting fungicides on return bloom has been proposed. Given that the leaf is the site of perception of the light signals that induce or prevent flowering, it follows that a stimulatory or inhibitory substance is translocated from the leaf to the site where flowers will form. Perhaps sterol-inhibiting fungicides mediate the perception of light by phytochrome, prevent the transformation of the perceiving organ by phytochrome or some derivative of phytochrome, or prevent the translocation of the substance responsible for floral stimulation. Many studies suggest that the translocatable substance responsible for floral initiation is gibberellic acid (GA) (Bidwell, 1979). Given that the sterol-inhibiting fungicide tridimefon has been shown to have many physiological effects on crop plants that can be reversed by simultaneous application of GA (Vyas, 1988), it is possible that return bloom in apple is reduced via reduced GA 
Table 4. Transpiration of 'McIntosh' apple leaves before and after application of the sterol-inhibiting fungicides bitertanol and flusilazolc. ${ }^{2, y}$

\begin{tabular}{|c|c|c|c|c|c|c|}
\hline \multirow{3}{*}{$\begin{array}{c}\text { Fungicide }^{\mathrm{x}} \\
\text { (g a.i./100 liter) }\end{array}$} & \multicolumn{6}{|c|}{ Transpiration $\left(\mu \mathrm{g} \mathrm{H}_{2} \mathrm{O} / \mathrm{cm}^{2}\right.$ per sec) } \\
\hline & \multicolumn{2}{|c|}{ Application I } & \multicolumn{2}{|c|}{ Application II } & \multicolumn{2}{|c|}{ Application III } \\
\hline & Pre- & Post- & Pre- & Post- & $\overline{\text { Pre- }}$ & Post- \\
\hline Bitertanol (8.4) & 5.97 & $6.02 \mathrm{~d}$ & 5.14 & $5.97 \mathrm{ab}$ & 2.83 & $3.66 \mathrm{a}$ \\
\hline$(16.8)$ & 6.12 & $6.17 \mathrm{~cd}$ & 4.94 & $5.05 \mathrm{~cd}$ & 3.03 & $3.33 \mathrm{abc}$ \\
\hline Captan (70) & 6.66 & $8.23 \mathrm{a}$ & 5.10 & $6.39 \mathrm{a}$ & 3.22 & $3.11 \mathrm{~cd}$ \\
\hline Flusilazole (1.4) & 6.54 & $6.59 \mathrm{~cd}$ & 4.87 & $4.60 \mathrm{~d}$ & 2.93 & $2.90 \mathrm{~d}$ \\
\hline$(2.8)$ & 6.02 & $6.11 \mathrm{~d}$ & 5.11 & $5.37 \mathrm{bc}$ & 2.69 & $3.26 \mathrm{bcd}$ \\
\hline$(5.6)$ & 6.33 & $7.01 \mathrm{bc}$ & 5.37 & $5.13 \mathrm{~cd}$ & 2.95 & $2.99 \mathrm{~cd}$ \\
\hline No fungicide & 6.59 & $7.67 \mathrm{ab}$ & $5.25^{\circ}$ & $5.43 b c$ & 2.92 & $3.57 \mathrm{ab}$ \\
\hline$P<$ & 0.44 & 0.0001 & 0.55 & 0.0001 & 0.32 & 0.0001 \\
\hline
\end{tabular}

${ }^{2}$ Data are the means of 36 measurements from a randomized complete-block design with four blocks, three replicate trees per treatment, and three leaves per tree. Measurements taken from the fourth expanded leaf from the terminal shoot apex.

'Mean separation in columns by Duncan's multiple range test, $P<0.05$.

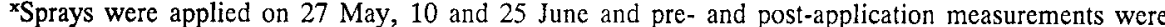
taken on 26 and 28 May, 9 and 13 June, and 24 and 27 June 1986, respectively. Applications I, II, and III represent the second, third, and fourth seasonal fungicide application to the orchard (first spray was applied on 12 May).

synthesis in the leaves, altered translocation of GA from the leaves to the site of floral initiation, or altered response of the potential floral apex to translocated GA. Support for the hypothesis of reduced GA synthesis is available from studies by Buchenauer et al. (1984) who showed that extracts of barley seedlings treated with triazole fungicides contained lower amount of gibberellin-like compounds than-untreated seedlings.

Sterol-inhibiting fungicides were associated with changes in leaf diffusive resistance in all three experiments (Table 3). All three sets of pre-application data showed that there were no significant treatment effects and all three sets of post-application data revealed highly significant treatment effects; however, the treatment effects were not consistent among experiments (Table 3). After the first application, only captan had reduced diffusive resistance relative to the sterol-inhibiting fungicides and the nonsprayed control. After the second application, flusilazole at the low rate and bitertanol at the high rate stimulated diffusive resistance relative to captan and the nonsprayed control. With the third application, bitertanol at both rates reduced diffusive resistance relative to captan and no fungicide.

Transpiration was influenced by sterol-inhibiting fungicides after all three applications (Table 4). As with diffusive resistance, all three sets of pre-application data showed no significant treatment effects, whereas all three sets of post-application data revealed highly significant treatment effects. After the first application, all sterol-inhibiting fungicide treatments, except the high rate of flusilazole, led to reduced transpiration relative to captan and no fungicide. With the second application, all sterol-inhibiting fungicides, except the low rate of bitertanol, reduced transpiration relative to captan. Only the low rate of flusilazole showed reduced transpiration relative to both captan and the nonsprayed control. Following the third appli- cation, captan and the low and high rates of flusilazole showed reduced transpiration relative to the nonsprayed control. Note that the low rate of flusilazole reduced transpiration relative to the nonsprayed control in all three tests.

These data on reduced transpiration are in agreement with data presented by Fletcher and Nath (1984) who observed that triadimefon at $20 \mu \mathrm{g} \cdot \mathrm{ml}^{-1}$ reduced transpiration in wheat, peas, and soybeans by $49 \%, 29 \%$, and $19 \%$, respectively, after soil treatments. The reductions prevented wilting and senescence. One positive effect of reduced transpiration could be more efficient water use by plants growing in semi-arid areas. It may be possible that higher yields of some crops could be forthcoming from such a strategy, although, in this system, transpiration reductions were transient. These observations on reduced transpiration could help explain why, in some studies, apple yields were reduced following repeated applications of sterol-inhibiting fungicides over several years (Hutcheon et al., 1986), although one would have expected to observe yield reductions as a result of lower individual fruit weight rather than fewer apples harvested, and this was not the case.

The mechanism by which triazole fungicides induce changes in transpiration could be related to osmotic adjustments in the stomata associated with increased potassium and anion concentration in the guard cells. The triazole growth regulator paclobutrazol caused altered diurnal leaf movements in soybean probably via a similar mechanism in the pulvinar region (Davis and Sankhla, 1987). Although some fungicides (e.g., captan) are known to increase cell membrane permeability, fenarimol, another triazole fungicide, does not (Simon, 1986). Therefore, it is unlikely that increases in cell membrane permeability are involved in transient transpiration changes.

I found no other reports of reduced tran- spiration due to the application of sterol-inhibiting fungicides under field conditions for an agronomic crop. Other studies have shown that sterol-inhibiting fungicides have nontarget effects on the host plant as well as other components of the apple orchard ecosystem (Biggs and Hagley, 1988; Hagley and Biggs, 1989). However, we do not know what effects the reductions in return bloom and transpiration have on yield and fruit size. More studies are needed to determine the impact of the increased use of sterol-inhibiting fungicides on the host plant as well as on nontarget microorganisms.

\section{Literature Cited}

Bidwell, R.G.S. 1979. Plant physiology. 2nd ed. Macmillan, New York.

Biggs, A.R. and E.A.C. Hagley. 1988. Effects of two sterol-inhibiting fungicides or populations of pest and beneficial arthropods on apple. Agr. Ecosystem Env. 20:235-244.

Biggs, A.R. and J. Warner. 1987. Control of primary and secondary apple scab infections with sterol-inhibiting fungicides. Can. J. Plant Pathol. 9:41-48.

Buchenauer, H., B. Kutzer, and T. Koths. 1984. Effects of various triazole fungicides on growth of cereal seedlings and tomato plants as well as on gibberellin content and lipid metabolism in barley seedlings. Z. Pflanzenkr. Pflanzenschutz 91:506-524.

Church. R.M., L. Copas, and R.R. Williams. 1984. Changes in fruit set, leaf size, and shoot growth of apple caused by some fungicides, insecticides. and a plant growth regulator. J. Hort. Sci. 59:161-164.

Davis. T.D. and N. Sankhla. 1987. Altered diurnal leaf movements in soybean seedlings treated with triazole growth regulators. Plant Cell Physiol. 28:1345-1349.

Fletcher, R.A. and V. Nath. 1984. Triadimefon reduces transpiration and increases yield in water stressed plants. Physiol. Plantarum 62:422-426.

Hagley, E.A.C. and A.R. Biggs. 1989. Effects of three fungicides on population of a phytophagous and several predacious mites (Acarina) on apple. Expt. Applied Acarology 6:253-256.

Hutcheon, J.A., J. Coyle, M.E. Holgate, and R.J.W. Byrde. 1986. Effects of fungicides on long-term-cropping and fruit quality of apple. Plant Pathol. 35:249-253.

Kelley, R.D. and A.L. Jones. 1981. Evaluation of two triazole fungicides for postinfection control of apple scab. Phytopathology 7:737-742.

Latham, A.J., W.A. Dozier, Jr., J.W. Knowles, and M.H. Hollingsworth. 1985. Suppression of apple bloom by fungicides that inhibit sterol biosynthesis. Plant Dis. 69:776-778.

Locke, T. and L. Andrews. 1986. Effects of fungicides on powdery mildew, tree growth and cropping of apple. Plant Pathol. 35:241-248.

Simon, P.J. 1986. Effects of some fungicides on cell membrane permeability in apple. Medical Faculty Landbouww. Rijksuniv. Ghent,. Belgium, 51/2a. p. 459-463.

Steel, R.G.D. and J.H. Torrie. 1980. Principles and procedures of statistics. 2nd ed. McGrawHill, New York.

Szkolnik, M. 1981. Physical modes of action of sterol-inhibiting fungicides against apple diseases. Plant Dis. 65:981-985.

Vyas, S.C. 1988. Nontarget effect of agricultural fungicides. CRC Press, Boca Raton, Fla. 